\title{
Problematika Pembelajaran Pendidikan Agama Islam (PAI) di SMK Negeri I Siabu Kabupaten Mandailing Natal
}

\author{
Oleh: Jumiarti dan Abdul Sattar Daulay
}

\begin{abstract}
Abstrak
Penelitian ini bertujuan untuk (1) Mengetahui keadaan pelaksanaan pembelajaran Pendidikan Agama Islam di SMK Negeri 1 Siabu, (2) Untuk mengetahui problematika pembelajaran Pendidikan Agama Islam di SMK Negeri 1 Siabu, (3) Untuk mengetahui upaya-upaya yang dilaksanakan untuk menanggulangi problematika Pendidikan Agama Islam di SMK Negeri 1 Siabu. Instrumen pengumpulan data observasi, dan interview (wawancara), Kemudian dianalisa secara kualitatif. Hasil penelitian ini menunjukkan bahwa pelaksanaan pembelajaran Pendidikan Agama Islam terlaksanakan secara aktif. Problematika yang dihadapi berasal dari kurikulum, siswa, guru, sarana prasarana dan pihak sekolah. Upaya untuk menanggulangi problematika tersebut dengan cara mengaktifkan pembelajaran dimana guru harus menguasai materi dan siswa pun meningkatkan motivasi, selanjutnya menyusun program sesuai dengan program sekolah dan memperbanyak kegiatan praktek ibadah.

Kata kunci: Problematika; pembelajaran PAI
\end{abstract}

\begin{abstract}
This study aims to (1) Know the state of the implementation of Islamic Religious Education learning at SMK Negeri 1 Siabu, (2) To find out the problems of learning Islamic Religious Education at SMK Negeri 1 Siabu, (3) To find out the efforts being carried out to overcome the problems of education. Islam at SMK Negeri 1 Siabu. The instrument for collecting data was observation and interview. Then it was analyzed qualitatively. The results of this study indicate that the implementation of Islamic Religious Education learning is carried out actively. The problems faced come from the curriculum, students, teachers, infrastructure and the school. Efforts to overcome these problems by activating learning in which teachers must master the material and students increase motivation, then compile programs according to school programs and increase worship practice activities.

Keywords: Problematics; PAI learning
\end{abstract}




\section{PENDAHULUAN}

\section{A. Latar Belakang Masalah}

Lembaga pendidikan adalah merupakan suatu sarana untuk dapat menciptakan peserta didik yang berkualitas dan berkemampuan maksimal. Dalam lembaga pendidikan proses belajar mengajar adalah merupakan faktor utama yang harus dilakukan sehingga kwalitas peserta didik dapat terwujud, serta menjadi manusia yang berkualitas. Guru, siswa, dan bahan pelajaran merupakan unsur yang dominan dalam proses pembelajaran. Jika salah satu tidak ada, maka unsur yang lain tidak dapat berhubungan secara wajar dan proses belajar mengajar tidak akan berlangsung dengan baik.

Keberhasilan pendidikan formal akan banyak ditentukan oleh keberhasilan pembelajaran, yakni keterpaduan antara kegiatan guru dengan siswa, kegiatan pembelajaraan yang berhubungan dengan cara guru menyajikan bahan dan cara siswa mempelajarinya. Pendidikan adalah tanggung jawab bersama antara keluarga, masyarakat dan pemerintah. Dalam hal ini orang tua harus mendidik anak-anak mereka di rumah dan masyarakat ikut andil untuk mengubah sikap dan tingkah laku ke arah yang benar dengan bantuan guru mendidik di bangku sekolah sebagai pendidikan formal.

Pada dasarnya mendidik adalah untuk menyempurnakan pendidikan agama dan hal-hal yang mencapai keberhasilan pendidikan. Salah satu wadah untuk mencapai tujuan pendidukan itu adalah jalur pendidikan sekolah. Sebagai mana yang di ungkapkan Uzer Usman bahwa:

"Proses belajar mengajar merupakan salah satu proses yang mengandung kegiatan guru dan siswa atas dasar hubungan timbal balik yang berlangsung dalam situasi edukatif untuk mencapai tujuan tertentu. Intraksi atau hubungan timbal balik antara guru dan siswa itu merupakan syarat utama bagi berlangsungnya proses belajar mengajar. Tidak sekedar hubungan antara guru dengan siswa, tetapi berupa intraksi edukatif. Dalam hal ini 
bukan hanya penyampaian pesan berupa materi pelajaran, melainkan penanaman sikap dan nilai pada diri siswa yang sedang belajar". ${ }^{1}$

Dikaitkan dengan profesi, guru agama idealnya memeiliki kompetensi lebih dari guru bidang studi lainnya. Dalam bidang studinya diharapkan kemampuannya menyentuh suatu yang abstrak ke dalam pengalaman siswa. Untuk itu selain memahami ajaran Islam secara luas guru agama dalam segenap penampilannya harus mencerminkan nilai-nilai Islami sehingga dapat menjadi teladan bagi anak didiknya. Dalam konteks ini Zakiah Daradjat menyatakan:

“Guru agama berbeda dengan guru bidang studi lainnya. Guru agama di samping melaksanakan tugas pengajaran, yaiu memberitahukan pengetahuan keagamaan, ia juga melaksanakan tugas pendidikan dan pembinaan bagi peserta didik, ia membantu pembentukan kepribadian, pembinaan akhlak, di samping menumbuhkan dan mengembangkan keimanan dan ketakwaan peserta didik". ${ }^{2}$

Dengan demikian guru agama idealnya seorang muslim yang taat, berkompetensi serta bertanggung jawab dalam membina seluruh aspek kepribadian anak didik sesuai dengan ajaran agama Islam. Oleh karena itu dalam agama Islam yang diwahyukan kepada Rasulullah SAW mengandung implikasi kependidikan yang dapat menjadi rahmat bagi sekalian alam. Oleh karena itu dalam agama Islam yang diwahyukan kepada Rasulullah Saw banyak mengandung implikasi kependidikan yang dapat menjadi rahmat bagi sekalian alam.

Agama Islam memiliki potensi yang mengacu kepada dua phenomena perkembangan yaitu:

\footnotetext{
hlm. 4

${ }^{1}$ Moh. Uzer Usman, Menjadi Guru Profesional (Bandung: Remaja Rosdakarya, 1995), ${ }^{2}$ Zakiah Daradjat, Pendidikan Islam Dalam Keluarga dan Sekolah (Jakarta: Ruhama, 1994), hlm.99
} 
1. Potensi psikologis dan pedagogis yang mempengaruhi manusia untuk menjadi sosok pribadi yang berkualitas baik dan menyandang drajat mulia melebihimakhlik-makhluk lainnya.

2. Potensi perkembangan kehidupan manusia sebagai khalifah dimuka bumi yang dinamis dan kreatif serta responsive terhadap lingkungan sekitarnya baik yang alamiah maupun yang ijtia'iah dimana Tuhan menjadi potensisentral perkembangan. $^{3}$

Untuk mengaktualisasikan dan memfungsikan potensi ditas diperlukan upaya kependidikan sistematis yang terencana berdasarkan pendekatan dan wawasan yang interdisipliner demi mengantisipasi pengaruh dan globalisasi yang sangat kompleks.

Namun dapat juga dikatakan sebagai hal yang menyangkut fungsinya pendidikan Islam jelas mempunyai peranan penting dalam peningkatan kwalitas manusia baik dalam penguasaan ilmu pengetahuan dan teknologi maupun dalam hal karakter, sikap moral dan penghayatan serta pengamalan ajaran agama, singkatnya Pendidikan Agama Islam secara ideal berfungsi membina dan menyiapkan anak didik yang berilmu, berteknologi, berketerampilan tinggi dan sekaligus beriman, beramal saleh dan bertaqwa.

Kompleksitas yang dihadapi para pelajar khususnya dapat dilihat dari kenyataan bahwa berbarengan dengan semakin tingginya tuntutan terhadap penguasaan ilmu pengetahuan dan teknologi, kian disadari pula perlunya pemantapan penghayatan dan pengalaman ajaran agama Islam untuk menghadapi kegoncangan nilai agama itu sendiri. Bahkan belakangan ini kita melihat terjadinya kebangkitan agama berupa intensifikasi penghayatan dan pengamalan ajaran-ajaran agama.

Dengan mempertimbangkan semua itu Pendidikan Agama Islam semestinya berorientasi kepada pembinaan dan pengembangan nilai-nilai agama dalam diri

${ }^{3}$ M. Arifin, Kapita Selekta Pendidikan Islam dan Umum (Jakarta: Bumi Aksara, 1991), hlm. 2 
siswa-siswi. Seperti para ahli mengatakan bahwa Pendidikan agama Islam bisa fungsional dengan memberikan penekanan khusus kepada dua hal yaitu:

1. Penguasaan ilmu pengetahuan dan teknologi

2. Penanaman pemahaman dan pengamalan ajaran agama. ${ }^{4}$

Berdasarkan studi pendahuluan yang penulis laksanakan bahwa pelaksanaan pembelajaran Pendidikan Agama Islam sudah dilakukan semaksimal mungkin yakni dengan melaksanakan antara lain: praktek pelaksanan ibadah, penyedian sarana dan prasarana yang mendukung pembelajaran Pendidikan Agama Islam, tetapi kenyataannya masih ada siswa yang tidak melaksanakan ibadah shalat secara teratur, tidak bisa membaca Alquran dengan bagus dan lancar, kurang memaknai sikap hidup Islami, dan akhlak yang jauh dari nilai-nilai Islam. Hal ini termasuk pada problematika pendidikan agama Islam.

Kenyataan tersebut menunjukkan bahwa tujuan pendidikan agama Islam di SMK Negeri 1 Siabu belum tercapai, dan masih ada problematika yang muncul. Hal ini mungkin disebabkan antara lain cara atau metode yang kurang tepat atau mungkin dipengaruhi oleh fasilitas yang terbatas, guru yang kurang professional, lingkungan yang tidak mendukung, materi yang kurang tepat dan lain-lain.

Untuk memberi jawaban permasalahan yang ada maka penulis mengadakan penelitian dengan memilih judul: "Problematika Pembelajaran Pendidikan Agama Islam (PAI) di SMK Negeri 1 Siabu Kabupaten Mandailing Natal”.

\section{KAJIAN TEORI}

\section{Pendidikan Agama Islam}

Secara etimologi atau bahasa Pendidikan Agama Islam terdiri dari tiga kata yakni pendidikan Pendidikan yang berarti proses pengubahan sukap dan tata laku seseorang atau kelompok orang dalam usaha mendewasakan manusia melalui upaya

${ }^{4}$ Azyumardi Azra, Pendidikan Islam Tradisi dan Modernisasi Menuju Milenium Baru (Jakarta: Logos Wacana Ilmu, 2002), hlm. 58-59 
pengajaran dan pelatihan, proses, cara, perbuatan mendidik. ${ }^{5}$ Agama adalah ajaran, sistem yang mengatur tata keimanan (kepercayaan) dan peribadatan kepada Tuhan Yang Maha Kuasa serta tata kaidah yang berhubungan dengan pergaulan manusia serta lingkungannya. ${ }^{6}$ Dan Islam adalah agama yang diajarkan oleh Nabi Muhammad Saw berpedoman kepada kitab suci Alquran yang diturunkan kedunia melalui wahyu Allah SWT. $^{7}$

Dari definisi di atas difahami bahwa Pendidikan Agama Islam adalah proses pengubahan sikap dalam usaha mendewasakan manusia melalui upaya pengajaran dan penelitian, proses, perbuatan, cara mendidik berdasarkan prinsip kepercayaan kepada Tuhan dengan kewajiban-kewajiban yang bertalian dengan kepercayaan yang diajarkan oleh Nabi Muhammad Saw berpedoman pada kitab suci Alquran, yang diturunkan ke dunia melalui wahyu Allah SWT.

Secara terminologi Pendidikan Agama Islam adalah:

"Usaha sadar yang berlangsung dalam kehidupan manusia untuk memenuhi kebutuhan hidupnya, melalui bimbingan, pengajaran, atau latihan dalam membentuk kpribadian serta mengembangkan fitrah yang di bawa sejak lahir, guna kebahagiaan dan kesejahteraan hidupnya". ${ }^{8}$

Pengertian lain tentang Pendidikan agama Islam adalah:

"Suatu bimbingan dan asuhan terhadap anak didik agar nantinya setelah selesai dari pendidikan dapat memahami apa yang terkandung dalam Islam secara keseluruhan, menghayati makna dan maksud serta tujuannya dan pada akhirnya dapat mengamalkannya serta menjadikan ajaran-ajaran agama Islam yang telah dianutnya itu sebagai pandangan hidupnya sehingga dapat mendatangkan keselamatan dunia dan akhiratnya kelak". 9

\footnotetext{
${ }^{5}$ Tim Penyusun Kamus Pusat Bahasa, Kamus Besar Bahasa Indonesia (Jakarta: Balai Pustaka, 2001), hlm. 263

${ }^{6}$ Ibid., hlm. 12

${ }^{7}$ Ibid., hlm. 444

${ }^{8}$ Yunus Namsa, Metodologi Pengajaran Agama Islam (Jakarta: Pustaka Firdaus, 2000), hlm. 23

${ }^{9}$ Zakiah Daradzat, Ilmu Pendidikan Islam (Jakarta: Bumi Aksara: 2008), hlm. 88
} 
Dari beberapa pendapat yang diuraikan diatas dapat disimpulkan bahwa Pendidikan agama Islam adalah usaha yang dilakukan seseorang untuk menanamkan nilai-nilai ajaran Islam kepada orang lain dalam rangka mengarahkan pertumbuhan dan perkembangannya menuju seorang pribadi muslim yang beriman dan bertaqwa.

\section{Tujuan Pendidikan Agama Islam}

Sebagaimana kita ketahui bahwa tujuan Pendidikan agama Islam adalah suatu hasil yang akan dicapai dalam setiap kegiatan karena tanpa tujuan arah keberhasilan yang akan diraih tidak akan sesuai dengan yang diharapkan. Demikian pula halnya dengan proses pendidikan tidak terlepas dari tujuan yang akan dicapai

Pada dasarnya tujuan Pendidikan Agama Islam itu adalah muslim yang sempurna atau manusia yang beriman, atau manusia yang beribadah kepada Allah Swt. Fungsi dan tujuan Pendidikan Agama Islam adalah:

1. Pengembangan keimanan dan ketaqwaan kepada Allah Swt serta akhlak mulia peserta didik seoptimal mungkin yang telah ditanamkan lebih dahulu dalam lingkungan keluarga.

2. Penanaman nilai ajaran agama Islam sebagai pedoman mencapai kebahagiaan hidup didunia dan akhirat.

3. Penyesuaian mental peserta didik terhadap lingkungan fisik dan sosial melalui Pendidikan agama Islam.

4. Perbaikan kesalahan-kesalahan, kelemahan-kelemahan peserta didik dalam keyakinan pengamalan ajaran agama Islam dalam kehidupan sehari-hari.

5. Pencengahan peserta didik dari hal-hal yang negativ budaya asing yang akan dihadapinya sehari-hari.

6. Pengajaran tentang ilmu pengetahuan keagamaan secara umum.

7. Penyaluran siswa untuk mendalami pendidikan agama kelembaga pendidikan yang lebih tinggi. ${ }^{10}$

\footnotetext{
${ }^{10}$ Departemen Pendidikan Nasional, Standar Kompetensi Mata Pelajaran PAI Sekolah Menengah Atas dan Madrasah Aliyah (Jakarta: Pusat Kurikulum Balitbang Depdiknas, 2003), hlm. 7
} 
Dari tujuan tersebut dapat ditarik beberapa kesimpulan yang hendak ditingkatkan, untuk kegiatan pembelajaranPendidikan Agama Islam diantaranya keimanan peserta didik terhadap ajaran agama Islam, pemahaman atau penalaran (intelektual) serta keilmuan pesert didik terhadap ajran agama, dan lain sebagainya.

Setelah mengetahui pengertiaan serta tujuan Pendidikan Agam Islam, maka untuk lebih mendalami Pendidikan Agama Islam tersebut setiap guru PAI harus memahami pendidikan Islam.

Disimpulkan bahwa ruang lingkup serta tujuan maka pembelajaran Pendidikan Agama Islam dilaksanakan seoptimal mungkin sesuai dengan ruang lingkup Pendidikan Agama Islam sehingga siswa memahami dan mampu menguasai ilmu atau materi Pendidikan agama Islam sehingga diamalkan dalam kehidupan sehari-hari.

Pembelajaran yang dimaksud adalah proses, cara, perbuatan menjadikan orang atau makhluk hidup belajar. ${ }^{11}$ Pembelajaran erat kaitannya dengan sekolah yaitu proses belajar dan mengajar, untuk itu penting untuk mencapai pembelajaran yang efektif.

Ada tiga faktor yang bersumber dari guru yang dapat mempengarui kualitas proses prmbelajaran yakni:

1. Persepsi guru sendiri terhadap rofesi guru.

2. Sikap guru terhadap pekerjaannya (termasuk sikap kepada siswa-siswi yang dihadapi).

3. Kemampuan yang harus dimikiki guru. ${ }^{12}$

Kegiatan pembelajaran merupakan sebuah proses. Pembelajaran tidak trerjadi dengan sendirinya melainkan dengan beberapa tahap dengan adanya unsur kesengajaan. Sebuah pembelajaran merupakan suatu kegiatan yang mempunyai tujuan. Untuk itu guru harus mempunyai langkah-langkah mulai dari perencanaan yang matang mencakup kurikulum, guru yang berkompetensi dan professional, siswa yang aktif belajar, penggunaan media dan metode pembelajaran,

\footnotetext{
${ }^{11}$ Tim Penyusun Kamus Pusat Bahasa, Kamus Besar Bahasa Indonesia, Op.Cit., hlm. 17

${ }^{12}$ Suharsimi Arikunto, Manajemen Pengajaran (Jaakarta: Rineka Cipta, 1993), hlm.21
} 
pemamfaatan sarana dan sebagainya. Guru yang tidak melaksanakan langkahlangkah tersebut maka dapat menimbulkan problematika pembelajaran.

\section{Problematika Pembelajaran Pendidikan Agama Islam}

Didalam pembelajaran Pendidikan Agama Islam telah lumrah dikatakan ada suatu problem atau masalah. Namun sebelum terlihat problematika yang dimaksud di dalam Pendidikan Agama Islam maka lebih dahulu diuraikan apa yang dimaksud dengan problematika. A.S Homby mengemukaan "problematica is difficult to deal with or understand;awkward of complex (problematika merupakan persoalan kesulitan atau tidak dipahami)". ${ }^{13}$

Dari defenisi-defenisi problematika di atas sudah jelas bahwa problematika identik apa yang dimaksud persoalan. Problematika adalah masalah atau persoalan dari pola pikir dan tingkah laku yang mengalami proses yang tidak terencanakan. Masalah atau persoalan tersebut merupakan titik awal suatu perubahan, dengan kata lain dengan ditemukannya suatu masalah maka perubahan dilaksanakn demi perbaikan menurut proses tertentu pula.

Adapun yang termasuk problematika pembelajaran Pendidikan Agama Islam meliputi:

a. Kurikulum

Kurikulum merupakan seperangkat rencana dan pengaturan mengenai isi dan bahan pelajaran, serta cara yang digunakan sebagai pedoman penyelenggaraan kegiatan pembelajaran. ${ }^{14}$

Dalam hal ini kurikulum Pendidikan Agama Islam mempunyai banyak materi dan ruang lingkup yang harus diberikan kepada anak didik sehingga mampu menguasai Pendidikan Agama Islam. Kurikulum Pendidikan Agma Islam merupakan sarana atau alat untuk memcapai tujuan Pendidikan Agama Islam yang sekaligus juga arah Pendidikan Agama Islam dalam rangka untuk

\footnotetext{
${ }^{13}$ A.S. Homby, Oxford Advanced Learners, Dictionary Of Current English (New York: Oxford, University Press, 1995), hlm. 922

${ }^{14}$ Mukhtar, Desain Pembelajaran Pendidikan Agama Islam (Jakarta: Mizaka Galiza, 2003), hlm. 30
} 
menumbuhkan atau membangun manusia seutuhnya. Pendidikan Agama Islam membawa, membina anak didik menjadi warga Negara yang baik sekaligus umat yang taat beragama. ${ }^{15}$ Untuk itu Pendidikan Agama Islam harus dikembangkan melalui perencanaan pengajaran. Pembinaan suatu kurikulum menentukan tujuan kurikulum yang paling efektif ialah paling berhasil dalam pencapaian tujuan Pendidikan Agama Islam.

b. Guru

Menurut UU RI No. 14 tahun 2005 tentang guru dan dosen, guru adalah pendidik professional dengas tugas utama mendidik, mengajar, membimbing, mengarahkan, melatih, menilai, dan mengevaluasi peserta didik pada pendidikan anak usia dini jalur pendidikan formal, pendidikan dasar, dan pendidikan menengah. ${ }^{16}$

Dapat disimpulkan bahwa guru Pendidikan Agama Islam ialah tenaga pengajar atau pendidik yang professional yang mendidik peserta didiknya berdasarkan pokok-pokok dan kajian-kajian yang meliputi ayat-ayat alquran , hadist dan kaidah kebutuhan, baik ia muamalah, urusan pribadi manusia, tata susila dan ajaran akhlak, guru yang dapat mengubah sikap, tingkah laku seseorang kearah yang lebih baik serta beriman dan bertaqwa kepada Allah SWT. Guru Agama bertanggung jawab untuk mendidik, mengajar, melatih, membimbing, dan menanamkan nilai-nilai Islam dengan baik bagi siswa, agar siswa mampu memahami dan menjalankan syariat Islam sengan baik.

c. Siswa

Salah satu problematika pembelajaran adalah dari siswa. Dimana pembelajaran berupaya menciptakan semangat belajar yang tinggi dan motivasi belajar. Hal ini merupakan masalah sebab terkadang siswa tidak mempunyai kesesuaian minat dan bakat terhadap mata pelajaran. Untuk itu

\footnotetext{
${ }^{15}$ Ibid., hlm. 26

${ }^{16}$ Tim Penyusun Undang-Undang Republik Indonesia No. 14 Tahun 2005 Tentang Guru dan Dosen (Bandung: Bani Quraisy, 2006), hlm. 83
} 
merupakan hal yang penting dalam mengetahui tingkat keberhasilan pembelajaran dengan memantau prestasi belajar siswa. Belajar adalah sebagai usaha penguasaan materi ilmu pengetahuan yang merupakan sebagian kegiatan menuju terbentuknya kepribadian seutuhnya. Dengan demikian belajar adalah usaha mengubah tingkah laku, perubahan yang membawa suatu perubahan pada individu-individu yang belajar, baik dengan penanaman ilmu pengetahuan, tetapi juga terbentuk kecakapan, keterampilan, sikap dan penyesuaian diri.

d. Sarana dan prasarana

Sarana dan prasarana sekolah yang meliputi gedung serta fasilitas dan alat perlengkapan yang mendukung aktifitas pembelajaran sangat dibutuhkan. Sarana dan prasarana yang cukup dan memadai dapat mendukung terlaksananya stretegi penetapan metode pembelajaran. Sarana dan prasarana dapat menciptakan lingkungan yang kondusif, sebab pendidikan terlaksana sesuai dengan kebutuhan siswa serta kemampuan guru.

e. Proses Belajar Mengajar

Dalam proses belajar ini tersirat adanya satu kesatuan kegiatan yang tak terpisahkan antara siswa yang belajar dan guru yang mengajar. Kedua kegiatan ini terjalin intraksi yang saling menunjang. Proses belajar mengajar juga merupakan aktivitas untuk mempengaruhi anak didik dalam satu situasi yang memungkinkan terjadinya interaksi antara guru dengan siswa, siswa dengan siswa, atau siswa dengan lingkungannya.

\section{METODE PENELITIAN}

Jenis penelitian ini adalah penelitian deskriptif. Penelitian ini menggunakan pendekatan kualitatif dengan tujuan untuk mengetahui apa saja problematika pembelajaran pendidikan agama Islam di SMK Negeri 1 Siabu Kabupaten Mandailing Natal.

\section{HASIL PENELITIAN}




\section{Problematika Dalam Melaksanakan Pembelajaran Pendidikan Agama Islam di SMK Negeri 1 Siabu}

Ada beberapa problematika yang ditemukan di SMK Negeri 1 Siabu. Problematika tersebut berasal dari kurikulum, guru, siswa, sarana prasarana, dan proses belajar mengajar.

Dalam menyampaikan materi pembelajaran Pendidikan Agama Islam guru beracuan kepada kurikulum. Hal ini sesuai dengan wawancara dengan guru PAI Ibu Ernita, S.Ag, pukul 09.00 mengatakan "Guru menyampaikan materi pembelajaran berdasarkan kurikulum, sebab kurikulum merupakan alat untuk mencapai keberhasilan pembelajaran". ${ }^{17}$ Berdasarkan kurikulum juga guru berupaya mengembangkan materi pembelajaran PAI. Dalam hal ini sekalipun kurikulum yang dilaksanakan berbeda di antara masing-masing guru, namun pengembangan materi sangat diperhatikan guru dan siswa pun menerima materi sebagaimana guru menyampaikannya dengan pengembangan yang mendalam. ${ }^{18}$

Selanjutnya problematika pembelajaran PAI berasal dari guru. Dan banyak hal yang berkaitan dengan permasalahan tersebut yang berkenaan dengan guru. Guru yang berkualitas dan professional adalah mampu merencanakan pembelajaran. Perencanaan yang dimaksud adalah baik dari jadwal efektifitas pembelajaran dan juga pelaksanaan evaluasi yang tidak kolektif diantara guru PAI.

Berkenaan dengan perencanaan pengajaran, guru juga harus menguasai materi. Guru yang menguasai materi sangat berpengaruh terhadap siswa dalam aktivitas pembelajaran. Siswa semakin bersemangat mendengarkan pembelajaran yang disampaikan guru. Namun tidak semua siswa merasakan menerima materi PAI sesuai dengan penguasaan guru terhadap materi.

Berdasarkan hasil observasi yang dilakukan peneliti di SMK Negeri 1 Siabu. Metode yang sering digunakan oleh guru adalah metode ceramah di depan kelas tepat

\footnotetext{
${ }^{17}$ Hasil Wawancara dengan Guru PAI Ernita S.Ag, Pada Tanggal 20 Februari 2015 di SMK Negeri 1 Siabu

${ }^{18}$ Berdasarkan Observasi di SMK Negeri 1 Siabu, Pada Tanggal 21 Februari 2015
} 
pada hari sabtu tanggal 21 Februari 2015 pukul 09.00 di kelas X, dalam pembelajaran PAI guru menggunakan metode ceramah dalam menjelaskan materi. Kemudian siswasiswi disuruh menghapal ayat yang berkenaan dengan materi pembelajaran disertai dengan artinya. ${ }^{19}$

Berdasarkan hasil wawancara dengan siswa SMK Negeri 1 Siabu pada hari senin, tanggal 23 Februari 2015 pukul 09.45 bahwa siswa mengatakan metode yang sering digunakan oleh guru yaitu metode ceramah dan diskusi. ${ }^{20}$

Semua guru selalu memotivasi belajar siswa, agar siswa semakin meningkat prestasinya. Demikian pula halnya dengan guru PAI berupaya memotivasi siswa agar siswa semakin giat dalam belajar. Dilihat dari hasil wawancara peneliti dengan ibu Ernita S.Ag, tanggal 24 Februari 2015 pukul 10.15 mengatakan bahwa: alasan saya memilih metode ceramah adalah karena kurang memadai buku paket untuk siswa. Maka untuk memahami siswa terhadap materi guru memilih metode ceramah. Kemudian memilih metode hapalan ini adalah agar siswa dapat menguasai materi dengan cepat. ${ }^{21}$

Dalam upaya melaksanakan pembelajaran PAI sehingga mencapai tujuan PAI maka guru PAI menganalisa materi yang diajarkan mulai dari membuka hingga menutup pelajaran. Akan tetapi karena keterbatasan kemampuan dan waktu maka tidak semua guru mampu menganalisa materi yang diajarkannya sesuai dengan prosedur pembelajaran yang dilaksanakan.

Berdasarkan observasi yang peneliti lakukan pada tanggal 24 Februari pukul 11.00. bahwa dalam rangka memotivasi belajar siswa banyak hal yang dilakukan guru. Seperti pemberian hadiah kepada siswa yang berprestasi dan hukuman kepada siswa yang malas dan bandel. ${ }^{22}$ Ini merupakan salah satu langkah yang dapat dilakukan dalam memotivasi belajar siswa. Namun tidak semua siswa menerima hukuman dan

\footnotetext{
${ }^{19}$ Hasil Observasi di SMK Negeri 1 Siabu, Pada Tanggal 21 Februari 2015

${ }^{20}$ Wawancara dengan Siswa Kelas XII, Muhammad Aziz, Pada Tanggal 23 Februari 2015 di SMK Negeri 1 Siabu

${ }^{21}$ Hasil Wawancara dengan Guru Pendidikan Agama Islam, Ernita S.Ag, Pada Tanggal 24 Februari 12015

${ }^{22}$ Hasil Observasi di SMK Negeri 1 Siabu, Pada Tanggal 24 Februari 2015
} 
hadiah bahkan ada diantara siswa yang tidak pernah menerima hadiah ataupun hukuman.

Problema yang ditemukan lagi di SMK Negeri 1 Siabu adalah tidak semua guru mengevaluasi hasil pendidikannya. Dimana ada beberapa guru yang tidak mengadakan evaluasi belajar hanya saja melaksanakan kesimpulan terhadap materi yang diajarkannya.

Problematika lainnya adalah aktivitas pembelajaran siswa yang tidak sama. Ada diantara siswa terkadang aktif dan terkadang mengalami kemalasan dalam belajar. Problema ini sangat penting diperhatikan sebab menyangkut aktivitas pembelajaran. Jika siswa tidak hadir dan bermalas-malasan dalam belajar maka keberhasilan belajar siswa tidak tercapai.

Di SMK Negeri 1 Siabu tidak semua siswa mempunyai tingkat pengetahuan yang tinggi. Hal ini merupakan masalah bagi tercapainya pembelajaran yang bagus. Untuk itu perlu mencari solusi terhadap permasalahan tentang penyebab ataupun hal yang perlu dilakukan agar siswa tidak bodoh.

Penggunaan alat atau media sangat berpengaruh bagi keberhasilan pembelajaran PAI. Media merupakan sarana dalam pengajaran yang diperlukan untuk membantu menjabarkan materi agar lebih mudah dipahami oleh peserta didik. Media sebagai alat bantu didalam proses belajar mengajar adalah suatu kenyataan yang tidak bisa dipungkiri, seorang guru sadar bahwa tanpa bantuan media maka bahan pelajaran atau segala sesuatu yang berhubungan dengan pelajaran sukar untuk dicerna dan dipahami oleh peserta didik.

Hal lain yang diperhatikan dalam pelaksanaan pembelajaran Pendidikan agama Islam bahwasanya media pembelajaran kurang diperhatikan, disebabkan guru jarang menerapkan media diwaktu proses belajar mengajar berlangsung.

Dari hasil wawancara peneliti dengan siswa bahwa pembelajaran PAI merupakan pembelajaran yang mengutamakan keterampilan. Untuk menerapkannya siswa harus diberi peragaan dengan media supaya siswa mengetahui bagaimana cara perawatan jenazah mulai dari cara memandikan, mengkafani, meshalatkan dan 
menguburkannya. Keberhasilan pembelajaran PAI tercapai jika sarana dan prasarananya lengkap yang mendukung keberhasilan PAI. ${ }^{23}$

Sarana dan prasarana sekolah dibuktikan dengan adanya ruangan kelas yang cukup memadai. Demikian pula halnya dalam bidang PAI sangat dibutuhkan ruangan praktek ibadah. Namun di SMK Negeri 1 Siabu sangat perlu sekali untuk melengkapi sarana dan prasarana yang ada. ${ }^{24}$

Pengelolaan kelas sangat berpengaruh bagi pelaksanaan pembelajaran sehingga tercapai hasil pembelajaran yang diharapkan. Guru dapat melakukan pengelolaan kelas melalui penataan tempat duduk siswa tidak diperbolehkan siswa laki-laki satu bangku dengan perempuan, selanjutnya tidak ada siswa yang ribut selama kegiatan belajar mengajar berlangsung. ${ }^{25}$ Selanjutnya guru juga harus melakukan manajemen kelas. Pengelolaan kelas dengan manajemen kelas berbeda. Menajemen kelas dilakukan mulai dari merencanakan pembelajaran hingga menutup pembelajaran.

Hal ini sesuai dengan wawancara dengan ibu Ernita, S.Ag pada tanggal 26 Februari 2015 pukul 11.30. bahwa pengelolaan kelas ini sangat perlu dalam pelaksanasaan pembelajaran, contohnya sebelum kegiatan belajar mengajar dimulai diadakan tata ruang kelas. Seperti mengatur tempat duduk. Membersihkan ruangan kelas sehingga tercipta suasara belajar yang aman, tentram, dan nyaman. ${ }^{26}$

Dalam melakukan pengelolaan kelas guru juga harus mampu untuk memahami situasi kelas dan kemampuan untuk bertindak selektif untuk memperbaiki kondisi, sehingga dapat menciptakan situasi belajar mengajar yang baik. Bagi seorang guru pengelolaan kelas merupakan suatu alat untuk mengembangkan kerjasama demi keberhasilan pembelajaran. Melalui pengelolaan kelas ini, maka perilaku siswa-siswi di kelas dapat diarahkan dan dibimbing sehingga suasana hati dan moral dapat dibangkitkan.

\footnotetext{
${ }^{23}$ Wawancara Dengan Sopiah Anna (Siswa SMK Negeri 1 Siabu), Pada Tanggal 24 Februari 2015 di SMK Negeri 1 Siabu

${ }^{24}$ Hasil Observasi di SMK Negeri 1 Siabu Pada Tanggal 25 Februari 2015

${ }^{25}$ Berdasarkan Observasi di SMK Negeri 1 Siabu Pada Tanggal 25 Februari 2015

${ }^{26}$ Hasil Wawancara dengan Guru Pendidikan Agama Islam, Ernita, S.Ag, Pada Tanggal 26 Februari 2015 di SMK Negeri 1 Siabu
} 
Kemudian setiap kelas harus ada piket yang bertugas unruk membersihkan kelas dan menjaga keindahan serta kenyamanan kelas selama berlangsungnya kegiatan belajar mengajar. Dengan demikian setiap sudah ada yang bertugas untuk menjaga kebersihan kelas dalam rangka menunjang kegiatan belajar mengajar yang dilaksanakan. Maka akan semakin mudah untuk mengikuti pembelajaran yang sedang berlangsung.

Setelah dilakukan penelitian terhadap belajar siswa SMK Negeri 1 Siabu terlihat bahwa dalam mengikuti pelajaran bidang studi Pendidikan Agama Islam minatnya sangat tinggi. Karena dalam setiap belajar guru agama Islam selalu memberikan bimbingan kepada siswa-siswi yang sedang belajar Pendidikan Agama Islam. ${ }^{27}$ Hal ini didukung dengan wawancara dengan salah satu siswa SMK Negeri 1 Siabu pada tanggal 27 Februari 2015 pukul 09.00. "Dalam mengikuti pelajaran bidang studi Pendidikan Agama Islam, kami merasa senang karena guru agama Islam kami selalu memberikan bimbingan dan arahan kepada kami. Dan sebelum pelajaran dimulai kami disuruh untuk membaca do'a". 28

Disamping itu pula dalam belajar Pendididikan Agama Islam guru kami senantiasa mengulang kembali pelajaran yang sudah diajarkannya kepada kami agar kami lebih giat dalam belajar. dalam belajar Pendidikan Agama Islam guru PAI senantiasa memberikan praktek bagaimana cara menyalatkan mayit, baru kami disuruh mempraktekkan satu-satu kedepan.

\section{KESIMPULAN}

Berdasarkan hasil penelitian yang ditemukan maka ada beberapa kesimpulan penelitian ini antara lain sebagai berikut:

1. Pelaksanaan pembelajaran Pendidikan Agama Islam di SMK Negeri 1 Siabu dilaksanakan dengan mengacup ada ruang lingkup PAI, fungsi dan tujuannya. Dari temuan peneliti bahwa pelaksanaan pembelajaran PAI baik.

${ }^{27}$ Hasil Observasi tanggal 27 Februari 2015 di SMK Negeri 1 Siabu

${ }^{28}$ Wawancara dengan Aisyah Fitriani, Pada Tanggal 27 Februari 2015 di SMK Negeri 1 Siabu 
2. Problematika yang ditemukan saat melaksanakan pembelajaran Pendidikan Agama Islam di SMK Negeri 1 Siabu beragam, sekalipun guru telah melakukannya menurut ruang lingkup, fungsi dan tujuan PAI akan tetapi terdapat problematika dari kurukulum, guru, siswa, sarana dan prasarana, dan proses belajar mengajar itu sendiri.

3. Upaya-upaya yang dilaksanakan dalam menanggulangi problematika pembelajaran Pendidikan Agama Islam di SMK Negeri 1 Siabu dilaksanakan oleh guru, siswa, dan sekolah. Upaya yang dilakukan sekolah melalui pembuatan RPP, penguasaan materi, penetapan indikator pembelajaran, penguasaan kurikulum, memotivasi siswa, dan pengelolaan pembelajaran. Upaya yang dilakukan siswa dengan mengikuti pembelajaran secara aktif, sumber buku yang dimiliki, dan aktif dengan praktek ibadah, serta meningkatkan minat belajar. Dari sekolah upaya yang dilakukan adalah penyediaan alat dan media, sumber belajar dan ruangan praktek.

\section{DAFTAR PUSTAKA}

Tafsir. Ahmad, Metodologi Pengajaran Agama Islam, Jakarta: Kalam Mulia, 2001

AM. Sardiman,Interaksi dan Motivasi Belajar Mengajar, Jakarta: Raja Grafindo Persada, 2011

An-Nahlawi.Abdurrahman, Prinsip-Prinsip dan Metode Penddidikan Islam, Bandung: diponegoro, 1985

Arif. Arma, Pengamatan Ilmu dan Metodologi Pendidikan Islam, Jakarta: Ciputat Pers, 2002

Arifin. M,Kapita Selekta Pendidikan Islam dan Umum, Jakarta: Bumi Aksara, 1991

Arikunto. Suharsimi, Manajemen Penelitian, Jakarta: Rineka Cipta, 2000

Darajat. Zakiah, Pendidikan Islam Dalam Keluarga dan Sekolah, Jakarta: Ruhama, 1994

, Ilmu Pendidikan Islam, Jakarta: Bumi Aksara: 2008 
, Metodologi Pengajaran Agama Islam, Jakarta: Bumi Aksara, 1996

Departemen Pendidikan Nasional, Standar Kompetensi Mata Pelajaran PAI, Jakarta: Pusat Kurikulum Balitbang Depdiknas, 2003

Djamarah. Syaiful Bahri dan Azwan Zaini, Strategi Belajar Mengajar, Jakarta: Rineka Cipta, 2006

Hamalik. Oemar, Kurikulum dan Pemmbelajaran, Jakarta: Bumi Aksara, 2011

Hamzah, Perencanaan Pembelajaran, Jakarta: Bumi Aksara, 2006

Homby. A.S, Oxford Advanced Learners, Dictionary Of Current English, New York: Oxford, University Press, 1995

Ladjit. Hafni , Pengembangan Kurikulim, Bandung: Quantum Teaching, 2005

Moleong. Lexy J, Metodologi Penelitian Kualitatif, Bandung: Remaja Rosdakarya, 2000

Muhaimin, Pengembangan Kurikulum, Jakarta: Rajawali Pers, 2010

Mukhtar, Desain Pembelajaran Pendidikan Agama Islam, Jakarta: Mizaka Galiza, 2003

Mulyasa. E, Kurikulum Tingkat Satuan Pendidikan, Bandung: Remaja Rosdakarya, 2006

Namsa. Yunus, Metodologi Pengajaran Agama Islam, Jakarta: Pustaka Firdaus, 2000

Nurdin. Syafruddin, Guru Profesional dan Implementasi Kurikulum, Jakarta:Quantum Teaching, 2005

Partono. Puis A. dan M. Dahlan Al-Barry, Kamus Ilmiah Populer, Surabaya: Arkola, 1995

Purwanto. Ngalim, Psikologi Pendidikan, Bandung: Remaja Rosdakarya, 2000

Ramayulis, Metodologi pengajaran Agama Islam, Jakarta: Kalam Mulia, 2001

Rosyadi. Khoiron, Pendidikan Profetik, Yogyakarta: Pustaka Pelajar, 2004 
Sabri.Ahmad, Strategi Belajar Mengajar, Padang: Quantum Teaching, 2005

Sudjana. Nana, Penilaian Hasil Proses Belajar Mengajar, Bandung: Remaja Rosdakarya, 1999

Sanjana. Wina, Strategi Pembelajaran Berorientasi Standar Proses Pendidikan , Jakarta: Kencana, 2007

Sastrapradja. M, Kamus Istilah Pendidikan dan Umum, Surabaya: Usaha Nasional, 1981

Slameto, Evaluasi Pendidikan, Jakarta: Bina Aksara, 1988

Suharsimi. Arikunto, Manajemen Penelitian, Jakarta: Rineka Cipta, 2000

Sukardi, Metodologi Penelitian Pendidikan, Yogyakarta: Bumu Aksara, 2003

Tim Penyusun Kamus Pusat Bahasa, Kamus Besar Bahasa Indonesia, Jakarta: Balai Pustaka, 2001

Tim Penyusun Undang-Undang Republik Indonesia No. 14 Tahun 2005 Tentang Guru dan Dosen, Bandung: Bani Quraisy, 2006

Usman. Moh. Uzer, Menjadi Guru Profesional, Bandung: Remaja Rosdakarya, 1995 